\title{
Policy Design of Government Affairs Distribution in the Future Forestry Sector: A Study in Indonesia
}

\author{
Hasim As'ari ${ }^{1 *}$, Irfan Ridwan Maksum ${ }^{2}$, Haula Rosdiana ${ }^{3}$, Haul Retno Kusumastuti ${ }^{4}$, Mayarni ${ }^{1}$, Tito Handoko \\ ${ }^{1}$ Study Program of Adminitration Science, Faculty of Social and Political Science, Universitas Riau, Pekanbaru, Riau 28293, \\ Indonesia \\ ${ }^{2}$ Department of Public Administration, Faculty of Administration Science, Universitas Indonesia, Depok, West Java 16424, \\ Indonesia \\ ${ }^{3}$ Department of Fiscal (Tax) Administration, Faculty of Administration Science, Universitas Indonesia, Depok, West Java \\ 16424, Indonesia \\ ${ }^{4}$ Department of Business Administration, Faculty of Administration Science, Universitas Indonesia, Depok, West Java 16424, \\ Indonesia \\ ${ }^{5}$ Department of Government Studies, Faculty of Social and Political Science, Universitas Riau, Pekanbaru, Riau 28293, \\ Indonesia
}

Corresponding Author Email: hasimasari@ lecturer.unri.ac.id

\section{https://doi.org/10.18280/ijsdp.160501}

Received: 9 May 2021

Accepted: 29 July 2021

\section{Keywords:}

policy design, government affairs distribution, forestry, site level

\begin{abstract}
The tugging of authority has an impact on forest management that is not optimal and sustainable at the level of implementation. Therefore, there is a need for solutions related to the design of the government affairs distribution policy in the future forestry sector, which is able to map who is the most appropriate party to manage the forest. Through the use of qualitative approach and interview methods, with 17 informants related to the implementation of government affairs in the forestry sector and collecting data through in-depth interviews and analyzed through interview methods, it was found that the design of government affairs distribution policies in the future forestry sector must distribute the affairs to only at the central government level and provincial level, but at the provincial level government forestry affairs in the future must be divided into two areas, namely forest administration and forest management.
\end{abstract}

\section{INTRODUCTION}

The Policy on Distribution of Government Affairs in the Indonesia Forestry sector since the beginning of independence until now has undergone several changes [1, 2]. At the beginning of independence, the governmental affairs distribution policy in the forestry sector was regulated in Government Regulation Number 64 of 1957 (PP 64/1957) concerning the Submission of Part of Central Government Affairs in the Field of Marine Fisheries, Forestry and People's Rubber to Regional Levels. This policy was valid until 1967, at that time a new policy was issued in the form of a Law, namely the Law of the Republic of Indonesia Number 5 of 1967 (Law 5/1967) concerning the Basic Provisions of Forestry. Subsequently in 1999, after the issuance of the Regional Autonomy Law, then Law 5/1967 concerning the Basic Provisions of Forestry was replaced again with a new policy, namely the Law of the Republic of Indonesia Number 41 of 1999 (Law 41/1999) concerning Forestry.

It is well known that forests provide benefits, may be classified according to ecological values, social values, and economic values. Although forests have traditionally been managed by society, it is expected that the current growth in the world population (now $>7,000$ million people) and the high economic growth of developing countries will lead to greater use of natural resources and of forest resources in particular [3]. The environment is a public good, and the problem of environment management is universal for all public goods: no one can be excluded from using it, and there is no competition in the process of its consumption [4]. So many problems caused by forests are not taken care of properly [5-7], so forestry matters must be dealt with more seriously, so that the objectives of forestry management as mandated in Republic of Indonesia.

Speaking of the distribution of government affairs, it cannot be separated from the concept of decentralization [8]. Decentralization is the transfer of planning, decision-making, or administrative authority to the fields of organizations, local administrative units, semi-autonomous and parental organizations, local governments, or nongovernmental organizations [9]. United Nations [10] provides a limit on decentralization as follows: "Decentralization refers to the transfer of authority away from the national capital whether by deconcentration (i.e. delegation) to field offices or by devolution to local authorities or local bodies". Interpretation of decentralization was very diverse, and that the approach to decentralization varied greatly from country to country [11]. However, in general the definition and scope of decentralization have been referred to so far, Rondinelli and the World Bank [9] argue that decentralization is the transfer 
of authority and responsibility for government functions from the central government to regional governments, semigovernmental institutions, and the private sector [12].

Then related to the distribution of government affairs, the manifestation of decentralization was regional autonomy and autonomous regions [13]. Both in the definition of autonomous regions and regional autonomy contain elements of authority regulating and managing. Authority to regulate and administer is the regional substance of autonomy which is held conceptually by the Regional Government. The concept of government affairs shows two important indicators, namely the function or activity and the origin of government affairs [13]. The surrender of government affairs by the Government to autonomous regions means that there is a distribution of government affairs that implicitly distributes authority between the Government and autonomous regions.

Policy research on the Distribution of Government Affairs, especially in the Forestry sector, is very important to do, because when viewed from the implementation of forest management in the field which is actually implemented by the Central Government and Regional Governments (Provinces and Regency/cities). This can be proven by the very high deforestation, especially in Riau Province. Based on data from the Riau Forest Rescue Network [14], Riau lost 565,197.8 hectares of natural forest cover in the range of 2009-2012, with an average area of deforestation occurring every year reaching 188 thousand hectares. In addition, the issue of forestry is a very important to be studied and must immediately get a way out, because the impact will be felt nationally and even internationally [5]. Forestry issues that have a national impact include; problems of deforestation, fire, smoke, conflicts between communities around the forest and companies, and even forestry corruption. Whereas the problems of forestry which impact covers on an international scale that is related to the problem of climate change and global warming. Therefore, it is very important to study more deeply about the governmental affairs in the forestry sector, especially from the perspective of those who are in charge of forests, namely the Central and Regional Governments $[2,15]$.

The problems above indicate that forest management carried out by the government is currently not optimal and even still causes complex forestry problems $[16,17]$ and the management of forests by the government has not managed to preserve forests that provide optimal and sustainable benefits for the people's prosperit [18]. The author suspects that this is the case because the Government Affairs of the Forestry Sector have not been properly distributed between the Central Government, Provincial and District/City, and there is still a pull-out of authority in the distribution of government affairs between the central and regional governments in forest management.

Policy design theorists argue that scientists must look further back in the causal chain to understand why policies succeed or fail, because the policy formulation and policy design processes significantly contribute to the results of their implementation [19]. Schneider and Ingram [19] also say that policy design influences not only policy implementation, but also political mobilization and the nature of democracy. Both of these opinions firmly say that policy design is very influential on the success of a policy implementation.

The Government Affairs Distribution Policy in the Forestry sector regulated in Law 23/2014 on Local Government, gives a portion and or authority to each level of government that is very different from the previous policy, where the largest portion is given to the Central Government, then some subsectors of forestry used to be distributed to the provinces, namely the Forestry Planning and Forestry Supervision subsector was withdrawn to the Central Government, and even at the Regency/City level there was no more portion or authority granted, except only one, namely the management of Regency/city Tahura. In fact, based on Law 23/2014, Government Affairs in the Forestry Sector are included in concurrent matters which require the division between the Central Government, Provincial, and the Regency/City.

Based on the experience of the policy that gives a large portion to the Center (PP 5/1967), forest management has a negative impact and is unable to manage forests optimally and sustainably [20], then there are indications that the Forestry Sector Government Distribution Policy design is regulated in Law 23/2014 on Regional Governments that give large portions to the Center will also be unable to achieve optimal and sustainable management and utilization of forest products. Therefore, there needs to be a solution related to the design of Government Affairs Distribution in the future Forestry sector that is capable of resolving forestry problems and is able to direct the management and utilization of optimal and sustainable forests.

The loss of forests in Indonesia has increased sharply over the past 12 years, according to a new study published in the Journal of Science. The study, led by Matt Hansen of the University of Maryland, found that Indonesia lost 15.8 million hectares between 2000 and 2012, ranked fifth behind Russia, Brazil, the United States and Canada in terms of forest loss. However, from the five forest countries above, based on percentages, Indonesia is ranked first from the rate of forest loss which is 8.4 percent [21]. In comparison, Brazil only lost half of that proportion. Of the 98 percent of forest loss in Indonesia, deforestation occurs in high density forest areas in Sumatra and Kalimantan, locations where conversion due to industrial plantations and oil palm plantations have developed very well over the past 20 years, Riau Province is the highest [22].

Based on data from the Riau Forest Rescue Network [14], in the last three years (2009-2012), Riau experienced a loss of natural forest cover of 565,197.8 hectares (0.5 million hectares), with an annual deforestation rate of 188 thousand hectares per year or the equivalent loss of 10 thousand futsal fields per day, and 73.5 percent of the destruction occurred in Peat Natural Forests which should be protected. Deforestation has increased throughout 2012-2013, which amounted to a total of 252,172 hectares of natural forest destruction by industrial plant-based corporations, compared to the previous year at 188 thousand hectares. Now the remaining natural forest is approximately 1.7 million hectares or only 19 percent of Riau's land area of 8.9 million hectares. A total of 252,172 hectares of deforestation occurred in the HGU concession area and were managed by the community, with a total area of 10,586 hectares (HGU concessions) and 241,586 hectares (outside the HGU concession). Beyond deforestation above, deforestation also occurs in protected forest areas, conservation of natural resources and beyond.

The policies in the form of laws and government regulations above are policies that are used as the basis for managing forests in Indonesia in the past and present, and from these policies indicate that normatively, forest management is carried out by the government, in the context of management and utilization forests in an optimal and sustainable way for the people's prosperity. The implementation of forest 
management that is normatively carried out by the government, both central and regional, through the distribution of affairs from the center to autonomous regions that has been running so far has not been able to resolve the problems that occur in relation to forestry affairs in Indonesia. The problem faced in relation to forest management in Indonesia is mainly the problem of deforestation that is so fast and getting worse.

\section{LITERATURE REVIEW}

\subsection{Decentralization}

Decentralization is a tool to support development and is intended to improve efficiency, equity and democracy. Efficiency increases because with greater local aspirations it should produce policies that are better in terms of targets achieved at lower costs [23]. Efficiency is often the most important thing for the central government, but benefits from aspects of equality [23]. Regarding the concept of decentralization, Robbins [24] says that why organizations should decentralize, because organizations must respond quickly to changing conditions that are at the point where the change takes place. Decentralization will encourage rapid action because it avoids the need to process information through vertical hierarchies. Decentralization can be done by the party closest to the problem. In addition to speed, decentralization can provide more detailed input for decision making. If the party closest to the problem makes a decision, then more specific facts relevant to the problem will be obtained. Functional decentralization means the transfer of authority from the Government to a group of people involved in certain government functions to regulate and manage it according to the jurisdiction of the function [25]. So, this concept also gives rise to autonomy for institutions that accept that authority at certain functions.

\subsection{Previous studies}

Government affairs that contain and involve the interests of the local community (locality) are held in a decentralized manner. Decentralized affairs can be done through details (ultra vires doctrine), general (general competence / open end arrangements), or a combination of both [25]. By combining the concepts of decentralization Robbins [24], Cheema and Rondinelli [9], and Hoessein [13], this study contributes to the concept of decentralization or the concept of future distribution of governmental affairs in the forestry sector where distribution of governmental affairs in the future must be distributed to the Site Level Forestry Institution which is closest to the forest area.

Similar research has been carried out, among others; Situmorang [26], which examines the "Model of Division of Government Affairs between Governments, Provinces, and Districts / Cities", this study still discusses the division of governmental affairs between the central and regional governments in general, by taking cases in education and health, and not yet reviewing division of governmental affairs in a sectoral manner especially in the forestry sector. Kartodihardjo [27] on "Institutional Capacity Issues and Direction of Forestry Policy", this study has not yet discussed what institutions are most appropriate to be given the authority to manage forests at the site level. Ekawati et al. [28], regarding "The Process of Making Intergovernmental
Authority Distribution Policy in Protected Forest Management and Its Implementation at the District Level", this study has not examined the main actors in the implementation of forest management in the regions, not yet reviewing the causes of forest management not optimal. Finally, Yohanes Kambey [29] on the Division of Government Affairs in the Forestry Sector (between the Central Government, Provincial Governments, and District / City Governments), this study has not discussed the design of appropriate government affairs in the forestry distribution policy in the future, not yet discussing the causes of management forests that have not been optimal, and have not discussed obstacles in the implementation of forestry affairs distribution policy.

Article 9 of Law No. 41/1999 concerning Forestry states that all forests in the territory of the Republic of Indonesia, including natural resources contained therein, shall be controlled by the State for the greatest prosperity of the people. Forest control by the State authorizes the Government to regulate and manage everything related to forests, forest areas and forest products. The granting of authority to the Government to carry out forest management includes within it the Central Government and the Autonomous Region Government. However, who is the most appropriate party to take care of the forest in the future? Whether the Central Government, Provincial Government, or Regency/City Government, or even other institutions. This will bring consequences to the changes in the Forestry Government Affairs Distribution Policy itself [30, 31].

Law 41/1999 on Forestry does not explicitly regulate the distribution of governmental affairs in the forestry sector, but it is regulated in its derivative policy, namely Government Regulation No. 44 of 2004 (PP 44/2004) concerning Forestry Planning. This regulation regulates the implementation of government affairs in the forestry sector and specifically in the forestry planning sub-sector. Furthermore, in 2007 another policy was issued in the form of a Government Regulation, namely Government Regulation of the Republic of Indonesia Number 6 of 2007 (PP 6/2007) concerning Forest Arrangement and Preparation of Forest Management Plans, and Forest Utilization. This Government Regulation regulates the implementation of governmental affairs in the forestry sector and specifically in the sub-sector of forestry management. Then, in the same year there was another policy specifically regulating the distribution of government affairs for all sectors including the Forestry Government Affairs, namely Government Regulation Number 38 of 2007 (PP 38/2007) concerning the Division of Government Affairs, between the Government, Provincial Local Governments, and Regency/City Local Government. Based on Government Regulation No. 38/2007 Article 2 verse 1-4, government affairs in the forestry sector are government affairs that are shared among levels and / or structures of government.

Furthermore, the last and most current Government Affairs Distribution Policy is the Republic of Indonesia Law Number 23 Year 2014 (Law 23/2014) concerning Local Government. This law is indeed about Local Government, but it also regulates the Distribution of Government Affairs for all sectors and includes Government Affairs in the Forestry sector. The Government Affairs Distribution Policy regulated in Law 23/2014 concerning Local Government, was previously regulated in a special policy in the form of a Government Regulation, namely in PP 38/2007 as stated earlier, but is now merged into one, which is included in Law 32/2014 concerning Local Government referred to. 
The governing policies related to the Distribution of Forestry Government Affairs as mentioned earlier, have different designs in distributing government affairs between the Central Government, Provincial Governments and Regency/City Governments. Some of them distributed Forestry Government Affairs between the Central Government and Provincial Governments, and some distributed the Forestry Government Affairs to the Regency/City Government. In addition, the distribution also varies, namely there are those who distribute Forestry Government Affairs to the regions (Provinces and Regency/cities) in large portions and some are small.

\section{METHOD}

This research was designed using a qualitative approach and interview method. A qualitative approach is characterized by in-depth interviews to describe how government affairs are distributed in the forestry sector in Indonesia. The research instruments in this study were the researchers themselves, so that the experience of researchers in the topic of research became a separate force for the enrichment of information retrieval and data analysis. Qualitative design processes extracting information until data analysis is done iteratively. Informants were selected purposively, inductive data analysis, grounded theory development was extended until the researchers got research answers in more depth to the research problem. The iteration process is carried out through sorting, selection, and categorization of results in the field, which is then used to support an exploration of cases that are interpreted ideographically [32].

How the process of distributing government affairs in the future forestry sector, Who the main Actors in the Distribution of Government Affairs in the Future Forestry Sector, How the Design of Distribution of Government Affairs in the Future Forestry Sector? In-depth interviews were conducted with actors from the Central Government and from the Local Government (Riau Province). The document review, in the form of a study of Law 41/1999 concerning Forestry and its derivative policies, including PP 38/2007 concerning the distribution of functions between the Central, Provincial and Regency/City Governments, and Law 23/2014 on Local Government. The informants in this study consisted of: Director General of Law Enforcement of the Indonesian Ministry of Environment and Forestry, Director of Regional Government Synchronization of the Ministry of Home Affairs of the Republic of Indonesia, Head of Evaluation, Dissemination and Library Section, Secretariat of Research and Innovation Agency of the Indonesian Ministry of Environment, Section Head of BPKH concerning Keplanologian , Ministry of LHK (Vertical Agency of Ministry of Environment and Forestry in Riau Province), Head of Forestry Service of Riau Province, Head of Planology of Forestry Service of Riau Province, Head of Planning for Forestry Service of Riau Province, Head of KPHP Minas Tahura Forestry Service of Riau Province, Head of KPHP Tasik Besar Serkap Serkap Besar Riau Province, Head of Environmental Infrastructure Division of Riau Province Bappeda, Head of Planning Sub-Division SDA Bappeda Riau Province, Head of Planning SDA Bappeda Riau Province, Head of Planning Section and Inventory of Forestry Service of Riau Province, Head of Planning Sub-Division of Riau
Province Forestry Service Program, NGO who pursue ten forest rescue namely the Coordinator of Riau Forest Rescue Network [14], Riau DPRD Member namely Secretary of Commission B of the Riau Provincial DPRD, Academic Policy Expert Academic of the Faculty of Forestry, Lancang Kuning Riau University, Chairperson of Siak Regency Bappeda, and community leaders around the reserve forest the small siak biosfes, represented by the Head of the Bad Bakul Village, Bukit Batu Subdistrict, Bengkalis Regency, and Sepahat Village Head, Bukit Batu District, Bengkalis Regency. The data analysis technique is qualitative analysis, which is processing and preparing data to be analyzed, reading the entire data, analyzing in more detail by coding data, describing settings, people, categories, and themes to be analyzed, linking themes - themes or descriptions in a series of stories, and show how these descriptions and themes will be restated in qualitative narratives / reports, conclusions.

\section{RESULTS AND DISCUSSION}

\subsection{The process of distribution of government affairs in the future forestry sector}

The results of the study indicate that the process of implementing government affairs in the forestry planning subsector is still not running optimally, especially in relation to the issue of the implementation of forest area gazettement and the implementation of the establishment of forest management areas. Likewise, the implementation of forestry affairs in the sub-sector of forestry management is still not optimal, particularly related to the establishment of KPH institutions that are still not optimally implemented, even though their existence is a prerequisite for the implementation of optimal and sustainable forest management. Furthermore, in the implementation of the forestry sub-affairs in the sub-sector of supervision, informants from the Regional Government acknowledged that they had not been optimally conducting supervision, so that many forestry cases were still unresolved to date such as cases of deforestation and overlapping forest areas.

Various forestry problems that still occur in the field indicate that the implementation of past forestry policies which in fact have been implemented by the central and regional governments is still not optimal, and still unable to resolve existing forestry problems. Though a myriad of policies governing forestry and in it are also regulated about the distribution of their affairs, what must be taken care of by the Center, what must be taken care of by the Province, and what must be handled by the Regency / city is clear. Therefore, this study offers a solution in order to solve the problems as mentioned before, and this solution is obtained based on the results of interviews in conducting research in the field. So that it is known how the design of the distribution policy of governmental affairs in the forestry sector between the government and autonomous regions is carried out. This is done with the aim that the implementation of forest management by the government can truly provide optimal benefits, namely as much as possible for the prosperity of the people and by continuing to preserve the forest.

Based on the results of the study through interviews with informants, it is known that the process of distributing government affairs in the future forestry sector is as follows: 
4.1.1 Must sit together, one mindfulness, and one orientation

In the process of designing a policy on the distribution of government affairs, especially in the forestry sector, all stakeholders must sit together, and not be done in a centralized or top down manner so as not to produce a centralized policy as well as the distribution of governmental affairs in forestry regulated in Law 23/2014 on Local Government. This happened because there was no involvement of regional stakeholders in its formulation. Furthermore, the process of distributing government affairs in the forestry sector should not be used as a venue for competing authority between the center and the regions. Both the center and the region must have one thought, one intention, and one goal in forest management, namely for sustainability and sustainability, and not solely seeking maximum profits without regard to the sustainability and sustainability of the forest. Because without a single orientation in managing the forest, the victims will be the forest itself and including the community and even animals in and around it.

4.1.2 The center makes macro policy and the rest please to the regions for creativity

Ideally in the Distribution of Forestry Government Affairs, the center should make Norms, Standards, Procedures, and Criteria (NSPK) related to good forest management procedures, and then control the implementation of affairs in the region. To carry out forest management, give it to regions for creativity and innovation in accordance with the characteristics of the region. The informant added, including in terms of granting permits to forest managers and forest areas were also given to the regions, so that the regions would have full authority and control over forestry business actors in the regions. In turn, regions will also have the authority to give penalties to permit holders who commit violations.

\subsubsection{Give full authority to the provincial government}

The current policy on the distribution of government affairs in the forestry sector is still not in line with the spirit of regional autonomy and tends to be still half-hearted, which has implications for implementing forest management in the regions. Local governments have difficulties in dealing with forestry problems that occur in the regions. The half-hearted distribution of authority also has implications for forest sustainability which is increasingly depleted and deforestation is accelerating. Therefore, the policy of distribution of governmental affairs in the field of future forestry must give full authority to the Provincial Government to implement forest management in the regions, because the regions are more aware of the real condition of forests and forest areas in the field.

4.1.4 Distribute the planning sub-sector and the forestry supervision sub-sector to the provincial government level

In order for the objectives of forest management to be achieved, then in the formulation and implementation of forestry policies still have to distribute the affairs of the forestry sector especially in the Forestry Planning Sub-Sector and the Forestry Supervision Sub-Sector to the Provincial Government level. The reasons that make it important to distribute the Forestry Planning Sub-Sector and the Forestry Supervision Sub-Sector to the Provincial Government level, because: a) those who know more about the state of the forest area, which includes forest areas and which are not included in the forest area anymore according to the existing conditions are parties that are close to the location of the forest area itself, in this case the Provincial Government, b) the distance between the supervisor and the supervised object will certainly be more difficult to do, on the contrary closer to the supervisor with the object being watched then the implementation will be more effective and efficient, regardless of the possibility of irregularities in the field, c) the number of millions of hectares of forests in the entire province of Indonesia, whether the Center can or is capable of encroaching all.

\subsubsection{Distribute forest management to site level forestry institutions}

The existence of forestry institutions at the site level in forest management is very important because these institutions directly deal with forests in the process of implementing forest management, starting from planning, organizing, implementing, and monitoring and controlling, so that their existence is called a prerequisite for the implementation of optimal forest management and sustainable, and these institutions have been referred to as Forest Management Units (FMU). After the authority of the Regency/city in the forestry sector is withdrawn to the Province and the Center, then the future management of forests located in the area must be carried out directly by the Site Level Forestry Institution namely FMU. FMUs must truly be the lowest management unit that manages forest areas at the lowest level, which are directly facing forest areas. In the future, the funds allocated for forest management must be carried out by the forest management or FMU management unit, so that the FMU will manage a lot of funds from the APBD, APBN, and even funds from abroad. Thus, the distribution of forestry government affairs to Site Level Institutions is very important, so that Site Level Institutions have clear authority, so that future forest management will continue to involve the region through Site Level Institutions and Provincial areas not only taking care of forest administration but also managing forests directly at the site level.

\subsection{Main actors in the distribution of government affairs in the future forestry sector}

The process of implementing the Forestry Government Affairs which is still not optimal and still leaves complex forestry problems in the field, is inseparable from the parties who carry out these authorities. Based on the results of the research that the parties involved in forest management include the Central Government, Provincial Governments through the Forestry Service, Private Sector, Forestry, Community and Higher Education NGOs. However, those who were most involved in managing past and present forests were the Provincial Forest Service, and the Regency/City Forest Service. All forests in the Province or Regency/city area are only managed by one Forestry Service in the Province plus the Forestry Service in each Regency/city.

The results of the study indicate that the implementation of forest management by the Forestry Service is still not optimal and still leaves many forestry problems in the field until now. This shows that the Provincial Government has not been able to take care of the forest, only relying on one Forest Service institution. Therefore, it is important to determine who the main actors in forest management in the region can solve various forestry problems in the future.

Based on the results of the study, it is known that the main actor who is able to solve the problem of forestry is the forestry 
institution at the site level, namely the FMU. The existence of $\mathrm{KPH}$ institutions has been regulated in laws and regulations, but until now it has not been fully implemented. Whereas the existence of FMU institutions is a prerequisite for the implementation of optimal and sustainable forest management. Therefore, in the future, in addition to the Provincial Forestry and Forestry Service Office, FMUs must also obtain a portion of the distribution of Forestry Government affairs. So, the main actors that must be considered in the distribution of governmental affairs in the field of future forestry include; Central actors namely the Ministry of Environment and Forestry and Provincial actors are the Office of Environment and Forestry and FMU as site-level institution.

The future FMU is the forest ruler, namely the Site Level Forestry Institution which has the most authority to manage the forest at the site level. Thus, all matters relating to the forest and all parties who carry out activities, both companies, community groups, and individuals in their working areas must be known and obtained their approval. The results of the study indicate that if the FMU has truly become the ruler of the forest, it can be believed that future forest management will be better. Especially with the issuance of Law 23/2014 on Local Government, the authority of the Regency/city in the field of forestry has ceased to exist, the province will be overwhelmed by taking care of vast forests with such a great distance. With the distribution of governmental affairs in the forestry sector to the Site Level Institution as a substitute for Regency/City, of course the Provincial Government will be more helpful, because Riau forests will be divided again into 32 regional units which are managed by 32 FMUs. Thus, the unit that will take care of the forest becomes more than the number of regencies/cities in Riau.

The division of forests into management units which will be handled by the FMU as Site Level Institutions, brings FMU as the only institution that becomes an extension of the hands of both the Central and Provincial Regions in forest management at the site level. All governmental affairs in the forestry sector at the site level are submitted to the FMU, so that in the future there will be no need for vertical forestry agencies in the area as they are today. This will certainly lead to better forest management, so that the objectives of optimal and sustainable forest management can be realized.

However, currently the role of the FMU as mentioned before is still not running, and to be able to optimize the role of the FMU in forest management in the future, there are several steps that must be fulfilled first by the Central and Provincial Governments, including:

First, immediately establish definitive FMU institutions. Based on the results of the study that Riau Province will establish 32 FMU institutions. However, until now there are only 5 FMU institutions that have been formed. Whereas the existence of FMU institutions is a prerequisite for the implementation of optimal and sustainable forest management 5 (five) existing FMUs consist of 4 (four) Production of FMUs and 1 (one) Concervation of FMU namely Tasik Besar Serkap of PFMU whose territory covers two districts namely Siak and Pelalawan, Minas Tahura PFMU whose territory covers three districts namely Pekanbaru, Siak, and Kampar, Tebing Tinggi PFMU, Kampar Kiri PFMU, and South Kuansing CFMU.

Second, Strengthening FMU institutional capacity. The results showed that one of the causes of FMU in Riau Province that had not run optimally was the position of FMU institutions which were still low, namely still in the form of service department technical unit, so that FMU did not yet have the authority to decide on policies and implement them themselves. So, to overcome this situation it is very necessary to strengthen the institutional capacity of FMUs in the regions.

Third, make strong regulations related to FMU authority. The results of the study show that currently FMUs have not carried out their duties optimally because there are no regulations that regulate FMU authority explicitly, FMUs have not been given the authority to take care of the forest as a whole, so that FMUs cannot do anything when there are deviations in forest management, both carried out by individuals and companies.

Fourth, there must be a clear regulation of employment relations. The current overlapping of authority between the Provincial Forestry Service and the FMU is also one of the causes for the implementation of FMU duties not yet optimal. On the one hand there are duties and functions of the FMU as stipulated in Government Regulations and Ministerial Regulations, but on the other hand the tasks and functions provided are also still given to the Forest Service. This resulted in the FMU being unable to do anything, coupled with the current position of the FMU which is still under the forestry service, making FMU increasingly powerless. Related to this, the government must immediately make regulations related to working relations between the FMU and the center, between FMU and the Provincial Forest Service, between FMU and companies, between FMU and the community, between FMUand NGOs, and between FMU and other third parties. This regulation can be a guide for each stakeholder in implementing future forest management.

Fifth, complete FMU facilities and infrastructure. As an organization at the site level, FMU is in desperate need of complete facilities and infrastructure. Incomplete facilities and infrastructure, such as today, make it very difficult for FMU officers to do work in the field. Medan, which must be passed by officers, is of course very diverse, there are things that are easy and some are difficult. Possible difficulties faced not only on road access, but in dealing with wild animals that might be encountered. The limited facilities and infrastructure will also make it difficult for field officers to monitor or supervise the forest and to forest managers operating in forest areas that are the FMU's working area. Both for monitoring or supervision carried out from land, water, and air lines all require complete facilities and infrastructure. Therefore, the existence of complete facilities and infrastructure is a must for FMUs to lead to optimal and sustainable forest management in the future.

Sixth, there must be socialization to provide understanding to all parties about the FMU concept. Related to this, the informant from Minas Tahura PFMU said that between the executive and regional legislatures at this time did not agree on the concept of FMU-based forest management. The current understanding is that with the presence of FMUs, the institutions that take care of the forest will become numerous, then regulations or regional regulations must be made. After being established and becoming a new institution, the consequence is that there must be operational costs and there will be work programs that must be implemented in the Regional budgeting and income. Thus it will have implications for the amount of expenditure in the Provincial budgeting and income. Therefore, this understanding must be anticipated by conducting socialization in order to unite the perception that with FMU-based forest management it is expected that optimal and sustainable forest management objectives will be easily realized. The socialization to unify the understanding 
regarding FMU-based forest management should be carried out by the Central Government, both from the Ministry of Environment and Forestry and from the Ministry of Home Affairs.

To make it easier to find out some steps that must be fulfilled by the Government in order to optimize the role of FMU as a Site Level Forestry Institution in the future, it can also be seen in Figure 1.

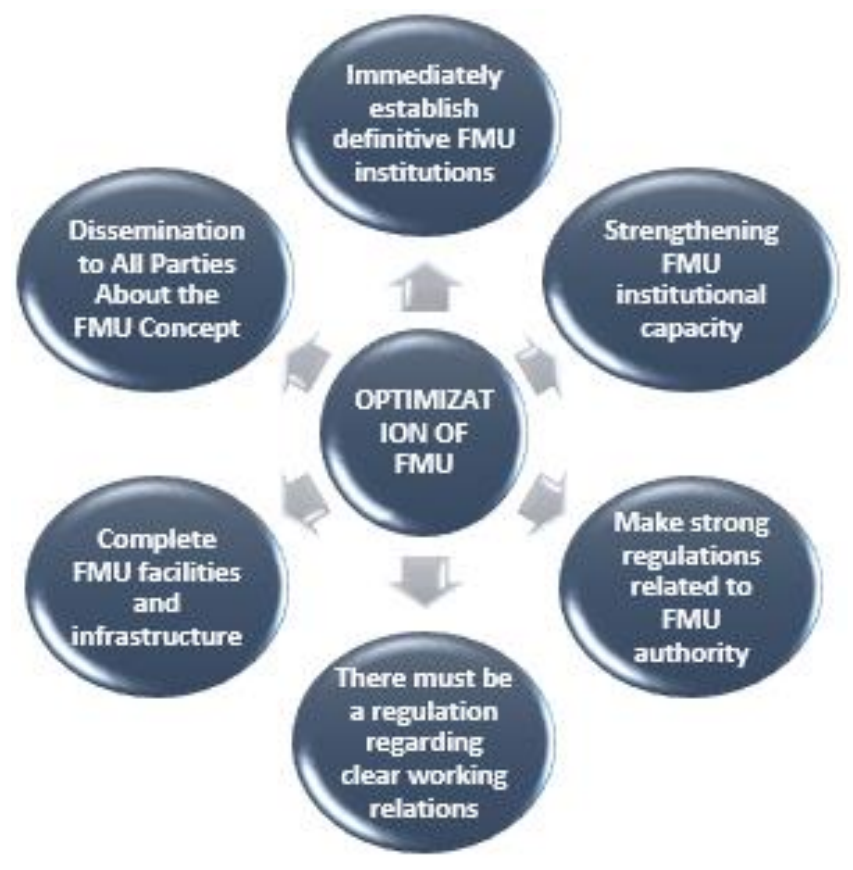

Figure 1. Optimizing the role of future FMUs

\subsection{Design of distribution of government affairs in the future forestry sector}

Based on research on legislation related to government affairs distribution policy in the forestry sector, that the design of the distribution of government affairs in the forestry sector currently regulated in Law 23/2014 on Local Government, has undergone changes when juxtaposed with the design of policies that regulate the distribution of government affairs Previous forestry regulated in Law 41/1999 concerning Forestry and its derivative policies, including those stipulated in PP 38/2007 which specifically regulates the distribution of government functions between the government, provincial government and regency/city government.

After the issuance of Law 23/2014 on Local Government, governmental affairs in the forestry sector are only distributed from the Central Government to the Provincial Governments only, while the functions at the Regency/city level become non-existent except only one of them is managing the TAHURA region whose territory is Regency/city. Because in Riau Province there is no TAHURA area within the Regency/city area, there is not one Regency/city in Riau that gets the distribution of government affairs in the forestry sector.

One of the reasons for the withdrawal of governmental affairs in the forestry sector to the Central and Provinces is because the stretch of forest area is located and covers the administrative boundaries of a regency/city, so it will be difficult if the management is handed over to the regency/city level where the forest boundaries are overlapped. However, the involvement of regions that are located close to the location of forest areas is very important in the framework of optimal and sustainable forest management, so the distribution of governmental affairs in the forestry sector will be different from the design of other government affairs distribution. The design of the distribution of governmental affairs in the forestry sector in the future will continue to be carried out in stages from the center to the regions, but it will not be carried out based on the level of the government structure consisting of the Center, Provinces and Regency/city.

Therefore, this study reveals various opinions from stakeholders as explained earlier, who want a change in the design of governmental affairs in the field of forestry distribution in the present, which is regulated in Law 23/2014 on Local Government to be the design of distribution of government affairs in the future. The change in the design of the distribution of governmental affairs in the forestry sector can be summarized in Table 1 .

The design of the distribution of government affairs in the future forestry sector is different from the design of the distribution of affairs in the present. These differences include: in the design of the distribution of government affairs in the forestry sector at present, the sub-planning and sub-sector of supervision is not distributed to the provincial level, but in the design of the distribution of government affairs in the future forestry sector is distributed to the provincial level and even to the level Site (FMU). In addition, in the distribution of government affairs in the future forestry sector, none of the governmental affairs in the forestry sector is distributed to the Regency/city level, but the distribution to the Regency/city that has been carried out has been transferred to the Site Level Forestry Institution (FMU). This is obtained based on the results of research that reveals various opinions and reasons from stakeholders as explained in advance.

Furthermore, to see the level of government that gets and does not get the distribution of governmental affairs in the forestry sector, both in the past, present, and in the future, is illustrated in Table 2 .

Table 2 explains that in the design of past government affairs distribution, all levels of government starting from the Center, Province, and Regency/City have the authority to carry out forest management. In the design of past government affairs distribution, policies related to forest management made by the Center were distributed to the level of Provincial and Regency/City Governments. Furthermore, in the design of the distribution of government affairs in the forestry sector today, the level of government that has authority in managing forests is only at the Central and Provincial levels. The level of regency/city government only has the authority to carry out the management of TAHURA within the Regency/city area. Meanwhile, in the design of the distribution of governmental affairs in the field of future forestry, the level of government that has the authority to manage forests is almost the same as the current design which does not distribute governmental affairs in the forestry sector to the regency/city level, but instead, in the design of governmental forestry distribution the future gives authority to the Site Level Forestry Institution (FMU) in forest management.

In addition to changes in the distribution design of government affairs in the forestry sector, stakeholders also want changes in the structure of implementation of forestry management. The structure of the implementation of forestry management that runs today is as Figure 2. 
Table 1. Design of the distribution of forestry sector affairs in the future

\begin{tabular}{|c|c|c|c|c|}
\hline No & Sub Field & The Past & The Present & The Future \\
\hline 1 & Forestry Planning & $\begin{array}{l}\text { - Central Gov. } \\
\text { - Province } \\
\text { - Regent / mayor } \\
\text { - Site Level (FMU) } \\
\text { (Government Regulations 44/2004 concerning Forestry } \\
\text { Planning) }\end{array}$ & - Central Gov. & $\begin{array}{l}\text { - } \text { Central Gov. } \\
\text { - Province } \\
\text { - } \text { Site Level } \\
\text { (FMU) }\end{array}$ \\
\hline 2 & Forest Management & $\begin{array}{l}\text { - Central Gov. } \\
\text { - Province } \\
\text { - Regent / mayor } \\
\text { - Site Level (FMU) } \\
\text { - Individuals } \\
\text { - Cooperatives } \\
\text { - Indonesian Private Business Entity (BUMS) } \\
\text { - Regional/state-owned Business Entity (BUMD / BUMN) } \\
\text { - Community } \\
\text { (Law } 41 / 1999 \text { on Forestry and Government Regulation } \\
\text { 6/2007 concerning Forest Management and Formulation of } \\
\text { Forest Management Plans, and Forest Utilization) }\end{array}$ & $\begin{array}{l}\text { - Central Gov. } \\
\text { - Province }\end{array}$ & $\begin{array}{l}\text { - } \text { Central Gov. } \\
\text { - Province } \\
\text { - } \text { Site Level } \\
\text { (FMU) }\end{array}$ \\
\hline 3 & $\begin{array}{l}\text { Research and } \\
\text { Development, } \\
\text { Education and } \\
\text { Training, and Forestry } \\
\text { Counseling } \\
\end{array}$ & $\begin{array}{l}\text { - Government } \\
\text { - College } \\
\text { - Business world } \\
\text { - Community } \\
\text { (Law 41/1999 on Forestry) }\end{array}$ & $\begin{array}{l}\text { - Central Gov. } \\
\text { - Province }\end{array}$ & $\begin{array}{l}\text { - Central Gov. } \\
\text { - Province }\end{array}$ \\
\hline 4 & Forestry Supervision & $\begin{array}{l}\text { - Central Gov. } \\
\text { - Province } \\
\text { - District / City } \\
\text { - Community } \\
\text { (Law 41/1999 on Forestry) }\end{array}$ & - Central Gov. & $\begin{array}{l}\text { - } \text { Central Gov. } \\
\text { - Province } \\
\text { - Site Level } \\
\text { (FMU) }\end{array}$ \\
\hline 5 & $\begin{array}{l}\text { Conservation of } \\
\text { Biological Resources } \\
\text { and their ecosystems }\end{array}$ & Included in the sub-sector of forest management & $\begin{array}{l}\text { - Central Gov. } \\
\text { - Province } \\
\text { - District / City (Only } \\
\text { manage the TAHURA } \\
\text { of District / City) } \\
\end{array}$ & $\begin{array}{l}\text { - } \text { Central Gov. } \\
\text { - Site Level } \\
\text { (FMU) }\end{array}$ \\
\hline 6 & $\begin{array}{c}\text { Watershed } \\
\text { Management }\end{array}$ & Included in the sub-sector of forest management & $\begin{array}{l}\text { - Central Gov. } \\
\text { - Province }\end{array}$ & 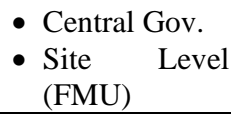 \\
\hline
\end{tabular}

Source: Processed Researchers, 2018

Table 2. Levels of government that get and do not get the distribution of government affairs in the forestry sector

\begin{tabular}{|c|c|c|c|c|c|c|c|c|c|c|c|c|c|}
\hline \multirow{2}{*}{ No } & \multirow{2}{*}{ Sub Field } & \multicolumn{4}{|c|}{ The past } & \multicolumn{4}{|c|}{ The present } & \multicolumn{4}{|c|}{ The future } \\
\hline & & Ct. & Pr. & Ds/Ct & $\mathbf{S}$ & Ct. & Pr. & Ds/Ct & $\mathbf{S}$ & Ct. & Pr. & Ds/Ct & $\mathbf{S}$ \\
\hline 1 & Forestry Planning & $\sqrt{ }$ & $\sqrt{ }$ & $\sqrt{ }$ & $\sqrt{ }$ & $\sqrt{ }$ & $\mathrm{X}$ & $\mathrm{X}$ & $\mathrm{X}$ & $\sqrt{ }$ & $\sqrt{ }$ & $\mathrm{X}$ & $\sqrt{ }$ \\
\hline 2 & Forest Management & $\sqrt{ }$ & $\sqrt{ }$ & $\sqrt{ }$ & $\sqrt{ }$ & $\sqrt{ }$ & $\sqrt{ }$ & $\mathrm{X}$ & $\mathrm{X}$ & $\sqrt{ }$ & $\sqrt{ }$ & $\mathrm{X}$ & $\sqrt{ }$ \\
\hline 3 & $\begin{array}{l}\text { Research and Development, Education and } \\
\text { Training, and Forestry Counseling }\end{array}$ & $\sqrt{ }$ & $\sqrt{ }$ & $\sqrt{ }$ & $\mathrm{X}$ & $\sqrt{ }$ & $\sqrt{ }$ & $\mathrm{X}$ & $\mathrm{X}$ & $\sqrt{ }$ & $\sqrt{ }$ & $\mathrm{X}$ & $\mathrm{X}$ \\
\hline 4 & Forestry Supervision & $\sqrt{ }$ & $\sqrt{ }$ & $\sqrt{ }$ & $\mathrm{X}$ & $\sqrt{ }$ & $X$ & $X$ & $X$ & $\sqrt{ }$ & $\sqrt{ }$ & $\mathrm{X}$ & $\sqrt{ }$ \\
\hline 5 & $\begin{array}{l}\text { Conservation of Biological Resources and } \\
\text { their ecosystems }\end{array}$ & \multicolumn{4}{|c|}{$\begin{array}{c}\text { Included in the sub-sector of forest } \\
\text { management }\end{array}$} & $\sqrt{ }$ & $\sqrt{ }$ & $\sqrt{ }$ & $\mathrm{X}$ & $\sqrt{ }$ & $\mathrm{X}$ & $\mathrm{X}$ & $\sqrt{ }$ \\
\hline 6 & Watershed Management & \multicolumn{4}{|c|}{$\begin{array}{c}\text { Included in the sub-sector of forest } \\
\text { management }\end{array}$} & $\sqrt{ }$ & $\sqrt{ }$ & $\mathrm{X}$ & $\mathrm{X}$ & $\sqrt{ }$ & $\mathrm{X}$ & $\mathrm{X}$ & $\sqrt{ }$ \\
\hline
\end{tabular}

Based on field research, the structure will be changed in the future by strengthening the site-level management function as a substitute for the Regency/City level whose affairs have been drawn to the Center and the Province through Law 23/2014 on Local Government. The structure of future forest management consists of Central, Provincial and Site-Level (FMU). Based on the results of the study, that the structure of future forest management will be better than the forest management structure that runs to this day. Where, the problem of overlapping activities between the Forestry Service and the FMU that have often happened will be overcome, because in this structure there is a very different distribution of affairs between official affairs that deal with forestry administration and FMU affairs that deal with technical forestry affairs.

The future forest management structure implies that, in distributing government affairs in the forestry sector to the regions in the future, it must pay attention to two different institutional functions, namely as forest administration and as forest management. Governmental affairs in the forestry sector relating to forest administration are distributed to the Provincial Government and carried out by the Provincial Forestry Service, while the forestry affairs related to forest management must be distributed to the Province and carried out by the Site Level Forestry Institution (FMU). The 
Provincial Forestry Service does not carry out forest management duties in the sense that the Provincial Forestry Service in the future does not implement forest management but carries out forest administration duties or carries out forestry administration duties, while FMUs do the opposite. The party that carries out the task of forest administration in the future is the Center and the Provincial Forest Service, while the party that carries out forest management in the future is a Site-level Forestry Institute (FMUs).

The future structure of forest management should be aligned between the Provincial Forest Service and the FMU in order to strengthen the institution of FMU institutions. One of the tasks of the FMU in the future is to make policies or strategies for managing forests that are under its authority, if the FMU is only limited to the Service Technical Implementation Unit, of course, it must wait for orders from the Office to be able to move. With its equal position, there will be no more intervention by the Office in implementing forest management by FMUs.

Based on field research, the structure of future forest management can be described as Figure 3.

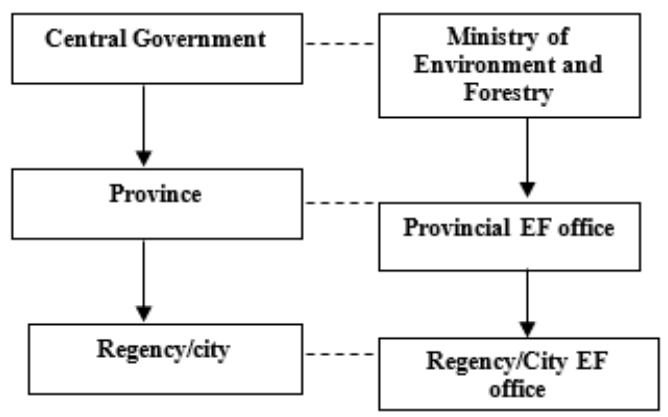

Figure 2. Implementation structure of forest management in the past and present

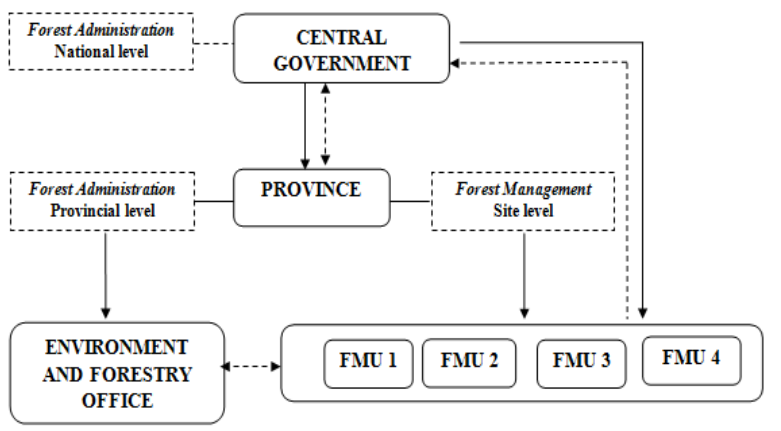

Figure 3. Forest management structure in the future

Based on the picture of the Structure of Future Forest Management, it can be reflected that the distribution of Forestry Affairs Government Affairs is carried out at the Central and Provincial Government level only. However, at the provincial level, government affairs in the future of forestry must be divided into two areas, namely the field of forest administration carried out by the Provincial Office of Environment and Forestry and the field of forest management carried out by FMU as Site Level Forestry Institutions. Strengthening Site Level Institutions in forest management can be carried out with the concept of functional decentralization, where the Central Government makes this Institution itself as a separate Institution from the Provincial LHK Service and directly under the Governor, with the main function being site management, in order to achieve forest management optimal for the welfare of the community and maintaining forest sustainability.

\section{CONCLUSION}

Based on the description above, it can be concluded that the design of government affairs distribution policies in the forestry sector in the future include: First, having to distribute Forest Management to Provincial Government Levels including the Forestry Planning and Forestry Supervision SubSector which is not distributed by government affairs distribution policies present time. Second, distribute Forest Management to the Site Level Forestry Institution (FMU) as the Main Actor and regional representation in forest management in the region, including the Forestry and Forestry Supervision Planning Sub-Sector which was previously distributed to the Regency/City Level, but in the design of government affairs distribution policies the present is not distributed anymore. FMU as a future Site Level Forestry Institution needs to be optimized with the following steps: 1) Immediately form the definitive FMU organization, 2) Strengthen KPH institutional capacity, 3) make strong regulations related to FMU authority, 4) there must be regulations on employment relations clearly, 5) Complete $\mathrm{KPH}$ facilities and infrastructure, and 6) there must be socialization to provide understanding to all parties about the FMU concept. Third, government forestry business distribution in the future is carried out at the Central and Provincial Government level, but at the Provincial level, future forestry affairs must be divided into two areas, namely the forest administration carried out by Provincial Forestry and Environment Service, and the forest management carried out by FMU as Site Level Forestry Institution.

\section{REFERENCES}

[1] Pambudi, A.S. (2020). The development of social forestry in Indonesia. Journal of Indonesia Sustainable Development Planning, 1(1): 57-66. https://doi.org/10.46456/jisdep.v1i1.11

[2] Muluk, M.R.K., Nugroho, Y.R.P. (2019). Intergenerational public goods approach for decentralizing forestry affairs. Wacana, 22(3): 193-203.

[3] Martn-Garca, J., Javier, J. (2012). Sustainable forest management: An introduction and overview. Sustainable Forest Management - Current Research. https://doi.org/10.5772/45839

[4] Lovrić, M., Posavec, S. (2010). The value of urban forests in residential land use. Forest Policy and Economics in Support of Good Governance, 58: 105. http://www.efi.int/files/attachments/publications/efi_pro ceedings_58_net.pdf.

[5] Giessen, L., Sarker, P.K., Rahman, M.S. (2016). International and domestic sustainable forest management policies: Distributive effects on power among state agencies in Bangladesh. Sustainability (Switzerland), 8(4): https://doi.org/10.3390/su8040335

335.

[6] Anderson, W.F.A., Maclean, D.A. (2015). Public forest policy development in new Brunswick, Canada: Multiple streams approach, advocacy coalition framework, and 
the role of science. Ecology and Society, 20(4): 20. https://doi.org/10.5751/ES-07795-200420

[7] Sing, L., Metzger, M.J., Paterson, J.S., Ray, D. (2018). A review of the effects of forest management intensity on ecosystem services for northern European temperate forests with a focus on the UK. Forestry, 91(2): 151-164. https://doi.org/10.1093/forestry/cpx042

[8] Barr, C., Resosudarmo, I.A.P., Dermawan, A., Setiono, B. (2006). Decentralization of forest administration in Indonesia implications. In International Forestry Research.

[9] Cheema, G. Shabbir Rondinelli, D.A. (1983). Decentralization and development: Policy implementation in developing countries. Sage Publications.

[10] Kertapraja, E.K. (2010). Political Configuration of Decentralization and Regional Autonomy Past, Present and Challenges. http://digilib.fisipol.ugm.ac.id/handle/15717717/15998.

[11] Devas, N. (1997). Indonesia: What do we mean by decentralization? Public Administration and Development, 17(3): 351-367. https://doi.org/10.1002/(SICI)1099162X(199708)17:3<351::AID-PAD955>3.0.CO;2-J

[12] Cadman, T., Sarker, T., Muttaqin, Z., Nurfatriani, F., Salminah, M., Maraseni, T. (2019). The role of fiscal instruments in encouraging the private sector and smallholders to reduce emissions from deforestation and forest degradation: Evidence from Indonesia. Forest Policy and Economics, 108: 1-10. https://doi.org/10.1016/j.forpol.2019.04.017

[13] Hoessein, B. (2002). Perspektif jangka panjang desentralisasi dan otonomi daerah. Kebijakan Desentralisasi Dan Otonomi Daerah Dalam Jangka Panjang. https://adoc.pub/perspektif-jangka-panjangdesentralisasi-dan-otonomi-daerah.html.

[14] Muslim, R. (2014). Catatan Akhir Tahun 2013. Jikalahari. http://jikalahari.or.id/kabar/catatanakhirtahun/penebang an-hutan-alam-di-riau-buruk-rupa-tata-kelolakehutanan-indonesia/.

[15] Fisher, L.A., Kim, Y., Latifah, S., Makarom, M. (2017). Managing forest conflicts: Perspectives of Indonesia's forest management unit directors. Forest and Society, $1(1)$ : 8-26. https://journal.unhas.ac.id/index.php/fs/article/download /772/pdf/34938.

[16] Poffenberger, M. (2000). Communities and Forest Management in South Asia. IUCN.

[17] Sotirov, M., Pokorny, B., Kleinschmit, D., Kanowski, P. (2020). International forest governance and policy: Institutional architecture and pathways of influence in global sustainability. Sustainability (Switzerland), 12(17): 7010. https://doi.org/10.3390/su12177010

[18] Tobergte, D.R., Curtis, S. (2013). Forest policies, legislation and institutions in Asia and the Pacific; trends and emerging needs for 2020. In Journal of Chemical Information and Modeling, 53(9).

[19] Fischer, F., Miller, G.J., Sidney, M.S. (2007). Handbook of Public Policy Analysis: Theory, Politics and Methods. CRC Press.

[20] Santoso, I. (2008). Perjalanan Desentralisasi Pengurusan Sumber Daya Hutan Indonesia. Ten Years Along: Decentralisation, Land and Natural Resources in
Indonesia, 1-7.

[21] Hansen, M.C., Potapov, P.V., Moore, R., et al. (2013). High-resolution global maps of 21 st-century forest cover change. Science, 342(6160): 850-853. https://doi.org/10.1126/science.1244693

[22] Mongabay. (2013). Forest Map Finding: Deforestation rate is increasing in Indonesia. http://www.mongabay.co.id/2013/11/15/temuan-petahutan-google-laju-deforestasi-meningkat-di-indonesia/.

[23] Larson, A. (2006). Desentralisasi Demokratis dalam Sektor Kehutanan: Pelajaran dari Afrika, Asia dan Amerika Latin. In Politik desentralisasi: hutan, kekuasaan dan rakyat (pp. 38-76). Center for International Forestry Research (CIFOR). https://www.cifor.org/knowledge/publication/2724/.

[24] Robbins, S.P. (1994). Teori Organisasi. Struktur, Desain \& Aplikasi. Arcan. https://opac.perpusnas.go.id/DetailOpac.aspx ?id=35235 7.

[25] Maksum, I.R. (2006). Desentralisasi dalam Pengelolaan Air Irigasi Tersier (Suatu Studi dengan Kerangka Konsep Desentralisasi Teritorial dan Fungsional di Kabupaten dan Kota Tegal, Jawa Tengah, di Kabupaten Jembrana, Bali, dan di Hulu Langat, Selangor, Malaysia). Makara, Sosial Humaniora, 10(1): 1-7. http://hubsasia.ui.ac.id/article/view/271.

[26] Situmorang, S. (2002). Model Pembagian Urusan Pemerintahan antara Pemerintah, Provinsi, dan Kabupaten/Kota. Universitas Indonesia. http://lib.ui.ac.id/detail?id=82346

[27] Kartodihardjo, H. (2006). Problem of institutional capacity and direction of forestry policy: Three cases study. Jurnal Manajemen Hutan Tropika, XII(3): 14-25. https://journal.ipb.ac.id/index.php/jmht/article/view/290 5.

[28] Ekawati, S., Kartodihardjo, H., Hardjanto, Dwiprabowo, H., Nurrochmat, D.R. (2011). Policy making process of authorities among levels of government in the protected forest management and its implementation in the regency level. Jurnal Analisis Kebijakan Kehutanan, 8(2): 132151. https://adoc.tips/download/analisis-kebijakankehutanan-journal-of-forestry-policyanal9b1ca120f4dc52694d2afc4ef65bb31d15807.html.

[29] Yohanes Kambey, S. (2015). Pembagian Urusan Pemerintahan Di Bidang Kehutanan (Antara Pemerintah Pusat, Pemerintah Daerah Provinsi, Dan Pemerintah Daerah Kabupaten/Kota). Katalogis, 3(1): 10-20. https://media.neliti.com/media/publications/151085-IDpembagian-urusan-pemerintahan-di-bidang.pdf.

[30] Wills, K., Paul, S., Tucker, G. (2005). Review of evidence for the formulation of forestry policy in England. Economic Research.

[31] Sheppard, J.P., Chamberlain, J., Agúndez, D., Bhattacharya, P., Chirwa, P.W., Gontcharov, A., Sagona, W.C.J., Shen, H. long, Tadesse, W., Mutke, S. (2020). Sustainable forest management beyond the timberoriented status quo: Transitioning to co-production of timber and non-wood forest products-A global perspective. Current Forestry Reports, 6(1): 26-40. https://doi.org/10.1007/s40725-019-00107-1

[32] Lincoln, Y.S., Guba, E.G. (1985). Naturalistic Inquiry (Newbury Park, CA: Sage Publications. Sage Publications. 